Walls of Empowerment 


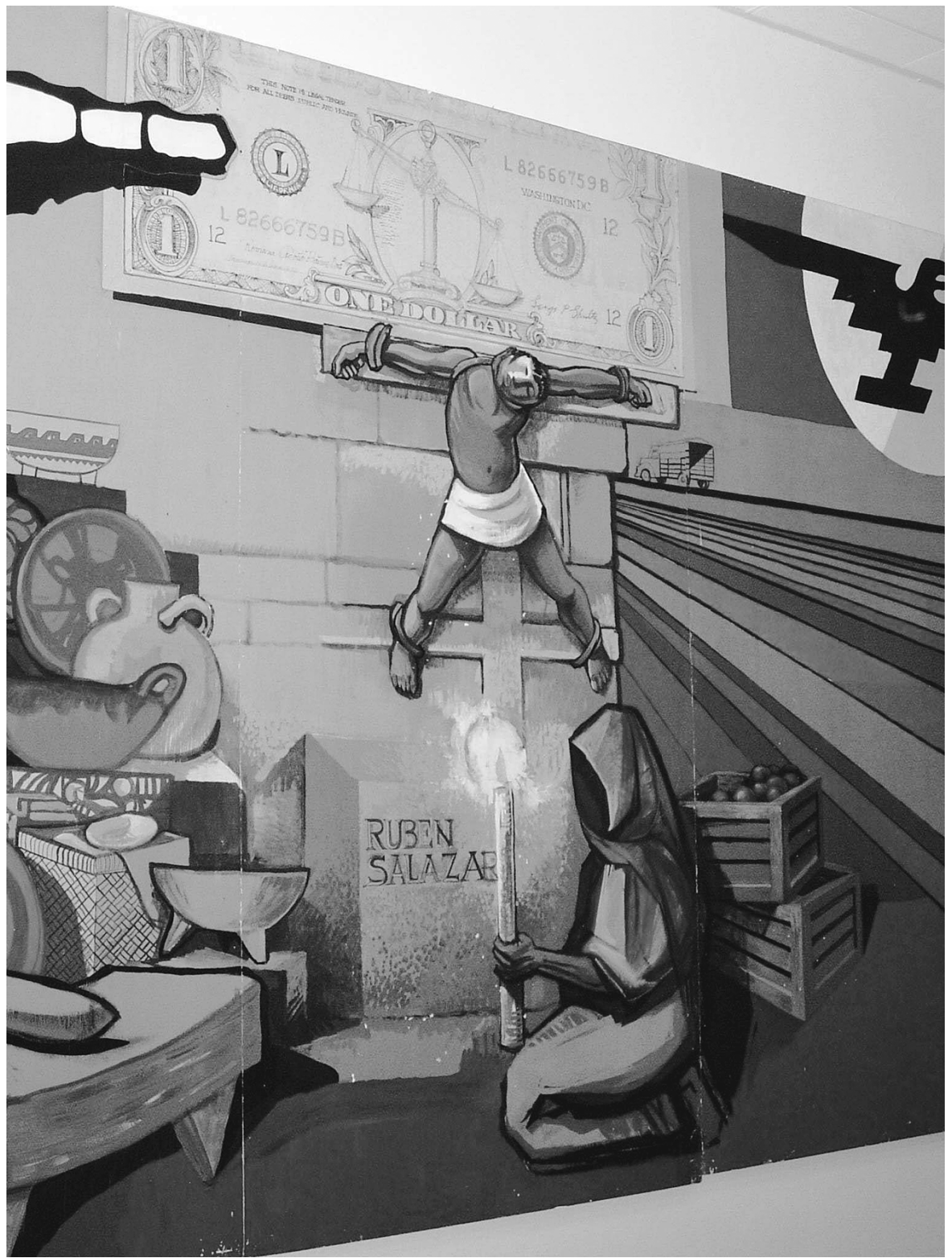

Sergio O'Cadiz, project director, assisted by Doris Baker, Emigdio Vasquez and Jennifer Winn, plus a team of 33 students of MEChA, (C) 1974, The MEChA Mural (detail), mural, Nealley Library, Santa Ana College, Santa Ana, CA. Courtesy of Nealley Library, Santa Ana College. 
G UISELA LATORRE

\section{Walls of Empowerment}

Chicana/o Indigenist Murals of California

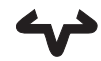

University of Texas Press, Austin 
Copyright (C) 2008 by the University of Texas Press

All rights reserved

Printed in the United States of America

First edition, 2008

Requests for permission to reproduce material from this work should be sent to:

Permissions

University of Texas Press

P.O. Box 7819

Austin, TX 78713-7819

www.utexas.edu/utpress/about/bpermission.html

( The paper used in this book meets the minimum requirements of ANSI/NISO Z39.48-1992 (RI997) (Permanence of Paper).

Library of Congress Cataloging-in-Publication Data

Latorre, Guisela, I970-

Walls of empowerment : Chicana(o) indigenist murals of California /

Guisela Latorre. - ist ed.

p. $\mathrm{cm}$.

Includes bibliographical references and index.

IS BN 978-0-292-71883-8 (cloth : alk. paper) — IS BN 978-0-292-71906-4 (pbk. : alk.paper)

I. Mexican American mural painting and decoration-Political aspects-California, Southern-2oth century. 2. Street art-California, Southern. 3. Indians in art. I. Title.

ND2635.C22S685 2008

$751.7^{\prime} 308968720794-\mathrm{dc} 22$

2008011228 
For my most precious little baby girl, Judith 
THIS PAGE INTENTIONALLY LEFT BLANK 